\title{
Drinking Water and Sanitation Conditions of Households in Tea Estates: A Case Study from the Giragama Estate
}

\author{
T. Sellathurai ${ }^{1}$, R.D.N.P. Rangalla ${ }^{1}$, K.A.D. Kumudinie Dheera ${ }^{1}$ and L.W. Galagedara ${ }^{2}$ \\ ${ }^{1}$ Postgraduate Institute of Agriculture, University of Peradeniya, Sri Lanka \\ ${ }^{2}$ Department of Agricultural Engineering, University of Peradeniya, Sri Lanka
}

\begin{abstract}
Safe drinking water and adequate sanitation are considered as basic human rigths. The understanding of how many people do not have access to drinking water and sanitation may help to assess the communities who do not have access to the fundamentals needs and facing spread of communicable diseases. In Sri Lanka, the estate sector has comparatively low health and sanitation condition than the rural and urban sectors. The population coverage for water and sanitation services for urban, rural and estate sectors are $100 \%, 82 \%$ and $62 \%$ and $100 \%, 82 \%$ and $55 \%$, respectively in 2012. The Millanium Development Goals and National Development Plan targets $80 \%, 90 \%$ and $100 \%$ of water for estate, rural and urban areas, respectively. In the case of sanitation they target 75\%, 85\% and $95 \%$ for estate, rural and urban areas respectively. This study was conducted to investiage the drinking water and sanitation situation of househods in two villages of the Giragama tea estate in the Central Province of Sri Lanka. The required data were collected through a structured questioner from a randomly selected 26 households from Kudaoya and 35 households from Kirimetiya watta of the Giragama estate. The main source of drinking water is unprotected spring in Kirimettiya watta and piped water in Kudaoya. The percentage of improved source of drinking water is $77.2 \%$ and $94.9 \%$ in Kirimettiya watta and Kudaoya, respectively. A $51.4 \%$ and $34.6 \%$ of water collection is done by females in Kirimettiya watta and Kudaoya, respectively. A 96.8\% of households in Kirimettiya watta have access to safer drinking water while it was $78.3 \%$ in Kudaoya. Boiling is found to be the major means of treatment of drinking water for $85.3 \%$ of the population tested. Kirimettiya watta has $87.3 \%$ improved sanitation facilities while it is $85.6 \%$ in Kudaoya. With respect to sanitation, $81.1 \%$ dispose children's faeces safely in Kirimettiya watta and this was $100 \%$ in Kudaoya. According to the overall analysis, it can be concluded that the two villages considered in this study has a fairly good improved drinking water facility and water availability. The households in Kudaoya have less awareness with regard to making drinking water safer. More than $85 \%$ of the households are using improved sanitation facilities and most of them have improved methods of childen's fecal removal.
\end{abstract}

KEYWORDS: Kirimettiya watta, Kudaoya, sanitation, drinking water corresponding author: T. Sellathurai, eMail: thusyanthi_sella@yahoo.com 


\section{INTRODUCTION}

Safe water and adequate sanitation are basic necessities for the health of every person on the planet. Yet, many people throughout the world do not have access to these fundamental needs. An important step towards resolving this global crisis is to understand its magnitude i.e. how many people lack access to drinking-water and sanitation?

Water sanitation and hygiene is directly linked with the United Nation's (UN) Millennium Development Goals (MDGs), and is now recognized by the $\mathrm{UN}$ as a fundamental human right, essential for human dignity and well being. The target $7 \mathrm{C}$ of goal 7 of the MDGs state that 'halve by 2015 , the proportion of population without sustainable access to safe drinking water and sanitation condition' (UN, 2013). According to the UN (2013), between 1990 and 2010, more than 2 billion people gained access to improved drinking water source i.e. the proportion of people using an improved water source rose from $76 \%$ in 1990 to $89 \%$ in 2010 . In 2011, 768 million people remained without access to an improved source of drinking water. Over 240,000 people a day gained access to improved sanitation facilities from 1990 to 2011 and despite the progress, 2.5 billion people in developing countries still lack access to improved sanitation facilities (UN, 2013).

Table 1: The estimated coverage (000) for those with existing access to water and sanitation and those that should have access if MDG target and universal coverage is achieved.

\begin{tabular}{|l|l|l|l|l|l|}
\hline \begin{tabular}{l} 
Populat $\begin{array}{l}\text { ion } \\
\text { subsect } \\
\text { ors }\end{array}$ \\
\cline { 2 - 6 }
\end{tabular} & $\begin{array}{l}\text { 2012 coverage } \\
\text { population } \\
\text { r }\end{array}$ & $\begin{array}{l}\text { Wate } \\
\text { Sanit } \\
\text { coverage } \\
\text { population } \\
\text { (2015) }\end{array}$ & $\begin{array}{l}\text { Water } \\
\text { ation }\end{array}$ & $\begin{array}{l}\text { Sanit } \\
\text { ation } \\
\text { coverage } \\
\text { water/sa } \\
\text { nitation } \\
\text { populati } \\
\text { on } \\
(2020)\end{array}$ \\
\hline Urban & 4360 & 436 & 4452 & 4229 & 4610 \\
\hline Rural & $\begin{array}{l}1194 \\
7\end{array}$ & 1203 & 13495 & $\begin{array}{l}1274 \\
5\end{array}$ & 15604 \\
\hline Estate & 792 & 728 & 1047 & 981 & 1362 \\
\hline
\end{tabular}

Source: IWA, Mapping human resource capacity gaps in the water supply and sanitation sector, country briefing note Sri Lanka 2013

What is the situation in Sri Lanka with respect to water supply and sanitation? In 2012, urban, rural and estate areas population is at $4,359,683,14,640,425$ and 1,277,489 respectively and it is projected to increase to $4,451,879, \quad 14,994,614$ and 1,285,169 respectively in 2015 and 4,609,891, 15,604,072 and 1,298,072 in 2020 (IWA, 2013).

The population coverage of water and sanitation services for urban, rural and estate areas are $100 \%, 82 \%$ and $62 \%$ and $100 \%$, $82 \%$ and $55 \%$, respectively (IWA, 2013). The National Water Supply and Drainage Board (NWSDB), Plantation Human Development Trust, CBOs, Estate Management Companies, Rural Municipal Councils are the main service providers for the estate sector and the estate sector use shared toilets with pit latrines or septic tanks and soakage pits for sanitaion technologies.

The MDG and National Development Plan targets 100\%, 90\% and 80\%of water supply for urban, rural and the estate sector, respectively. In the case of sanitation, the target 
is $95 \%, 85 \%$ and $75 \%$ for urban, rural and estate, respectively.

Table 1 indicates the estimated coverage for those with existing access to water and sanitation and those that should have access if MDG targets and universal coverage are achieved.

It is a common understanding that the estate sector in Sri Lanka has comparatively low educational qualification, economic levels and health and sanitation conditions. Accurate information about drinking water, sanitation and hygiene related issues are invaluable to national leaders, decision makers and stakeholders when making policy decisions. Sound, evidence based information can be used in a variety of ways, including; to assess progress toward national and international goals and targets, to promote increased investments in the sector and to focus attention on needy areas and efficiently allot resources. Therefore, we conducted a preliminary study to assess water supply and sanitation conditions among two selected communities at the Giragama estate in the Kandy district.

\subsection{Scope of the study}

The assessment investigates the drinking water and sanitation condition of households' in the Giragama estate with special reference to:

- Source of drinking water

- The collection of water

- Treatment of drinking water

- Owning of toilet facility and type of facility

- Awareness of disposal of children fecal matter
The study areas included in the survey include two villages naming Kudaoya and Kirimettiya watta. The majority of residents in the two villages' work at the Giragama tea estate.

\subsection{Background of the study area}

The Giragama estate is located at Yatinuwara GN division in the Kandy district. It comes under the Pussellawa plantations. According to the statistical report of Sri Lanka (2012), Kirimettiya watta and Kudaoya have a population of 937 and 958, respectively. The number of households occupied with drinking water facilities at Kirimetiya Watta and Kudaoya are 132 and 178, respectively while it is 237 and 254, respectively for sanitation facilities.

\section{MATERIALS AND METHODS}

In order to find out the drinking water and sanitation conditions we randomly selected 61 households from the Kudaoya (26) and Kirimetiya watta (35) villages in Giragama estate.

\begin{tabular}{|c|c|c|}
\hline & Improved & Unimproved \\
\hline $\begin{array}{l}\text { Drinking } \\
\text { water }\end{array}$ & $\begin{array}{l}\text { Piped water into } \\
\text { dwelling, } \\
\text { Plot or yard, public } \\
\text { tap/standpipe, tube } \\
\text { well/borehole, } \\
\text { protected dug well, } \\
\text { protected spring, } \\
\text { rainwater } \\
\text { collection }\end{array}$ & $\begin{array}{l}\text { Unprotected } \\
\text { dug well, } \\
\text { unprotected } \\
\text { spring, cart with } \\
\text { small tank / } \\
\text { drum, bottled } \\
\text { water a, tanker - } \\
\text { truck, surface } \\
\text { water (river, } \\
\text { dam, lake, } \\
\text { pond, stream, } \\
\text { canal, irrigation } \\
\text { channels) }\end{array}$ \\
\hline Sanitation $^{b}$ & $\begin{array}{l}\text { Flush / pour flush } \\
\text { to: } \\
\text { - } \quad \text { Piped sewer } \\
\text { system }\end{array}$ & $\begin{array}{l}\text { Flush / Pour } \\
\text { flush to: } \\
-\quad \text { Else ware } \\
\text { Pit latrine }\end{array}$ \\
\hline
\end{tabular}




\begin{tabular}{|l|l|l|}
\hline & $-\quad$ Septic tank & without slab / \\
$-\quad$ Pit latrine & open pit \\
Bucket \\
place / not & Hanging toilet / \\
hanging latrine \\
kIP latrine where & $\begin{array}{l}\text { No facilities or } \\
\text { bush or field }\end{array}$ \\
& $\begin{array}{l}\text { Pit latrine with } \\
\text { slab } \\
\text { Composting toilet }\end{array}$ \\
\hline
\end{tabular}

a - Bottle water is considered improved only when the household uses water from an improved source for cooking and personal hygiene

b - Shared or public facilities are not counted as improved Source: WHO/Unicef, 2006

A semi-structured questioner, which has been recommended by World Health Organization (WHO) and United Nations Children's Fund (UNICEF) for household survey on drinking water and sanitation condition was used for primary data collection.

This questioner included ten questions for analysis of drinking water and sanitation conditions. In this, the respective questions are presented in four parts: questions related to (i) basic household information, (ii) drinking water, (iii) sanitation, and (iv) disposal of children's faeces. The questions for drinking water provide information about the type of water source used, the time required to collect the water, who is responsible for fetching the water and about the treatment of drinking water.

The main focus on sanitation related questions were the type of sanitation facility used and whether the facility is shared with others. The main focus with respect to children's faeces was on the household practices for disposing of them. Table 2 shows the detailed classification of drinking water and sanitation condition according to (WHO and UNICEF, 2006). The obtained data were evaluated according to the indicated parameters.

\section{RESULTS AND DISCUSSIONS}

The main source of drinking water falls under the categories of piped water and unprotected springs in the Kirimettiya watta village and piped water and a protected dug well in the Kudaoya village. A Few number of households use the piped water, yard/plot, public tap/standpipe, tube well/borehole and surface water in Kirimettiya watta and unprotected dug well and unprotected spring in Kudaoya. In both cases they donot use bottled water for drinking purpose.A total of $51.0 \%$ of households use piped water in dwellings. According to the residents of the the Kirimettiya watta, their drinking water supplied through pipes is not or in good quality to be used as drinking water. They use water from an unprotected spring for drinking for which they have to spend around 10 to 30 minutes to collect the water. Some households with comparatively high income get drinking water from NWSDB connection by spending Rs. 16,000 per connection.

Even though the people in Kirimettiya watta depend on the unprotected spring for their drinking water source, the daily per capita water amount required to fulfill the basic household purposes is in a satisfied condition. They collect this water within 30 minuntes period in all situations. Even though the quantity of water needed is in a satisfied level, the quality of water seems to be at $n$ unsatisfactory level. We did not measure and compare the water quality in this study due to a lack of resources. Water quantity available is an important parameter for health and sanitation of a society, since there are some affordable 
treatment methods to clean the water to a drinkable quality.

Table 2 The summary of the drinking water and sanitation condition in Giragama estate

\begin{tabular}{|l|l|l|l|}
\hline Parameter & $\begin{array}{l}\text { Kirimettya } \\
\text { Watta }\end{array}$ & Kudaoya & Total \\
\hline $\begin{array}{l}\text { Accessibility } \\
\text { to water }\end{array}$ & $100 \%$ & $100 \%$ & $100 \%$ \\
\hline $\begin{array}{l}\text { Main source } \\
\text { of drinking } \\
\text { water }\end{array}$ & $\begin{array}{l}\text { Unprotected } \\
\text { spring }\end{array}$ & $\begin{array}{l}\text { Piped } \\
\text { water } \\
\text { into } \\
\text { dwelling }\end{array}$ & \\
\hline $\begin{array}{l}\text { Improved } \\
\text { source of } \\
\text { drinking } \\
\text { water }\end{array}$ & $77.2 \%$ & $94.6 \%$ & $83.9 \%$ \\
\hline $\begin{array}{l}\text { Gender issue } \\
\text { in water } \\
\text { collection }\end{array}$ & $51.4 \%$ & $34.6 \%$ & $44.3 \%$ \\
\hline $\begin{array}{l}\text { Safer drinking } \\
\text { water }\end{array}$ & $96.8 \%$ & $78.4 \%$ & $89.8 \%$ \\
\hline $\begin{array}{l}\text { Improved } \\
\text { sanitation } \\
\text { facility }\end{array}$ & $87.3 \%$ & $85.6 \%$ & $86.7 \%$ \\
\hline $\begin{array}{l}\text { Safe disposal } \\
\text { of children's } \\
\text { faeces }\end{array}$ & $81.1 \%$ & $100 \%$ & $87.6 \%$ \\
\hline
\end{tabular}

Burden of water collection mainly falls on the adult women in both villages. Of the survayed sample, $44.3 \%$ of the households depend on adult women to collect water from the source while $16.4 \%$ of the households share this burden with adult men. Only $4.9 \%$ of households need the contribution of female child under 15 years old to collect water. This information gives a sense that there are gender and generational disparities with respect to water hauling responsibilities. According to these results, women have the major responsibility in collecting water even though she goes to work in the estate to generate a household income.

Out of 61 households, $52(85.3 \%)$ treat water before using it for drinking and boiling is the main source of treatment $(83.6 \%)$. In addition, they use water filters and after boiling allows water to stand and settle and they strain it using a piece of cloth. This provides an indication that the drinking water used in the household is of adequate quality in most situations. An adequate water treatment method disinfects water, killing harmful pathogens, but $8 \%$ of the sample use inadequate methods of water treatment. In both cases, there are no water born diseases incidents in the last 2 weeks before the surveyed date.

A sanitation facility is considered adequate if it hygienically separates human excreta from human contact. The survey question about the sanitation revealed that $9.8 \%$ of households with the facility of a flush/pour flush to pit latrine and $90.2 \%$ of households with the facilities of a pit latrine with the slab. Therefore, the surface water contamination is highly prohibited ( unlikely) in both villages. However, there could be some possibilities to groundwater pollution, which is beyond the scope of this study.

Out of 61 households only nine households $(14.8 \%)$ that include 34 members, share their toilet facilities with two or three households. This amount is deducted from the improved sanitation facilities even though they have pit latrines with a slab. In most cases, the toilet facility is made through the estate owners. 
They give financial support to construct toilets in every house hold of those who are working in their estates.

The safe disposal of children's faeces is of particular importance. Since children's stool is most likely cause of faecal contamination to the immediate household environment.

The study reveals that only $13.3 \%$ of the household members use non hygienic methods to dispose the children's stool such as, put/rinsed into the ditches, left in open and thrown into garbage.

\section{SUMMARY AND CONCLUSIONS}

The collected data were evaluated according to the parameters indicated in Table 2 above and the obtained result was summarized in Table 3 . According to the analysed results, it can be concluded that the two villages considered in the survey have fairly good improved drinking water facility and water availability. The households in Kudaoya have less awareness with regard to making drinking water safer. More than $85 \%$ of the households use the improved means of sanitation facilities and most of them have the improved means of children's fecal removal.

\section{SUGGESTIONS FOR FURTHER IMPROVEMENT}

Further study on the educational standards, economic level and including more villages into the survey which are under this estate will improve the accuracy of the result and will facilitate the comprehensive analysis.
- The NWSDB should consider the quality of the water supplied to the community especially in Kirimettiya watta, they are not satisfied with the water supplied through the pipe.

- The household sanitation condition can be improved through village level monitoring and educational programs. This can be carried out by respective health sector officials (midwife), especially in the case of children faecal removal.

- Having a village level water sanitation monitoring system is necessary to maintain proper sanitation practices and rectify the damaged water sanitation system.

- Conducting village level awareness programs related to safer drinking water helps to improve the usage of improved drinking water source and treatment methods.

- From the observation, rather than water and toilet facilities, the personal hygienic conditions also need to be improved.

- Family planning also helps to improve their overall health and sanitation conditions.

\section{REFERENCES}

WHO/UNICEF. (2006). Core questions on drinking-water and sanitation for household surveys: WHO press. Available from http://www.who.int/water_sanitation.../oms_ brochure_core_questionsfinal2460.pdf

[Accessed: 06 ${ }^{\text {th }}$ December 2013]

IWA. (2013). Mapping human resource capacity gaps in the water supply and sanitation sector. country briefing note Sri Lanka. Available from: http://www.iwahq.org/hrcapacity [Accessed: 10th January 2014] 
UN, (2013). The Millennium Development Goals Report. United Nations New York. Available from: http://www.un.org/millenniumgoals/pdf/repo rt-2013/mdg-report-2013-english.pdf [Accessed: 27th January 2014] Department of Census and Statistics Sri Lanka, (2012) Population and housing data. 